\title{
Structural organization of the components of the cell wall from Candida albicans
}

\author{
José Ruiz-Herrera, ${ }^{1}$ Salvador Mormeneo, ${ }^{2}$ Pilar Vanaclocha, ${ }^{2}$ \\ Jaime Font-de-Mora, ${ }^{2}$ María Iranzo, ${ }^{2}$ Inmaculada Puertes ${ }^{3}$ \\ and Rafael Sentandre ${ }^{2}$
}

\footnotetext{
1 Departamentos de Genética y Biología Molecular y de Ingeniería Genética, Unidad Irapuato, Centro de Investigación y de Estudios Avanzados del IPN, Irapuato, Gto., México

2,3 Sección de Microbiología, Facultat de Farmacia, ${ }^{2}$ and Departamento de Bioquímica y Biología Molecular, Facultad de Medicina, ${ }^{3}$ Universitat de Valencia, Valencia (L'Horta), Spain
}

Author for correspondence: José Ruiz-Herrera. Tel: + 5246251600. Fax: $+5246250759,45657,51282$.
The organization of the components of the cell wall from Candida albicans was studied by means of sequential treatment with hot SDS, anhydrous ethylenediamine (EDA) and lytic enzymes, followed by chemical and microscopic analyses of the different separated fractions. The EDA-insoluble fraction retained the original morphology of the wall, which was destroyed by $\beta$-glucanase, but not by chitinase treatments. Staining with fluorescent lectins revealed distinct distributions of mannoproteins, glucans and chitin in the wall. Amino acid analysis of SDS-extracted walls, and the EDA-soluble and -resistant fractions gave similar results, with seven amino acids making up about $70 \%$ of the total protein weight. Treatment of the EDA-insoluble fraction with Zymolyase or chitinase released fragments of variable size whose susceptibility to these and other hydrolases suggests that they are made of glucan, chitin and mannan oligomers associated with proteins. Treatment of the Zymolyase-insoluble residue with chitinase released a series of low-molecular-mass oligomers made of neutral sugars, GIcNAc and amino acids, mainly lysine. It is suggested that they represent fragments of the core making up the scaffold of the cell wall of the fungus.

\section{INTRODUCTION}

The fungal cell wall is a coherent structure made up of an association of different components, mainly polysaccharides, proteins and lipids. This structure is rigidly assembled as demonstrated by wall resistance to shearing forces, which permits its almost intact preservation during isolation procedures. Accordingly, the possibility that the different components which make up the cell wall are associated not only by hydrogen or hydrophobic bonds, but also by covalent linkages has been entertained for some time (reviewed by Ruiz-Herrera, 1992). Experimental evidence exists that glucans and chitin are covalently-bound. The evidence is (a) the observation that glucan incorporation into the cell wall can be prevented by the chitin synthetase inhibitor polyoxin D (Benitez et al., 1976; Sonnenberg et al., 1983; Vries \& Wessels, 1975) and (b) the transformation of a nascent soluble form of wall glucan into an insoluble one (Wessels \& Sietsma, 1983) whose insolubility properties depended

Abbreviations: Con A, concanavalin A; EDA, ethylenediamine; Endo $\mathrm{H}$, endo- $\beta$ - $N$-acetylglucosaminidase; WGA, wheat germ agglutinin. on the integrity of chitin and, when this was destroyed, glucans became soluble (Mol \& Wessels, 1987; Sietsma \& Wessels, 1979, 1981). The existence of a direct linkage between both polysaccharides in the nascent wall of $C$. albicans protoplasts was suggested by the analysis of a high-molecular-mass product obtained by hydrolysis with chitinase (Surarit et al., 1988).

The existence of covalent bonding between proteins and glucans is suggested by the existence of specific wall protein populations which resist extraction with hot SDS and mercaptoethanol, and are rendered soluble only after glucan (Elorza et al., 1985; Herrero et al., 1987; Pastor et al., 1984; Sanz et al., 1985; Valentin et al., 1984) or chitin (Marcilla et al., 1991) hydrolysis. More direct evidence for such an association was obtained by the analysis of a wall protein which is recognized by a specific monoclonal antibody (4C12) in C. albicans. This protein which lacked $N$-glycosidically-bound mannan residues, acquired them after it became incorporated into the cell wall of the fungus (Elorza et al., 1989; Marcilla et al., 1991). More recently, Van Rinsum et al. (1991) provided convincing evidence for the existence of covalent bonding between 
glucans and mannoproteins in a mnn9 mutant of Saccharomyces cerevisiae.

In the present communication we describe experiments designed to provide an understanding of how the different polymers present in the cell wall of $C$. albicans are organized. Our approach consisted of the use of chemical and enzymic extraction procedures, followed by chemical and structural studies of the different separated fractions.

\section{METHODS}

Strain and culture conditions. Candida albicans ATCC 26555 was used in this study. It was maintained by periodic transfer on slants of Sabouraud agar (Difco). Inocula were obtained from 24-h-old cultures in modified Lee's medium (Lee et al., 1975) with the following composition: (per litre): $\left(\mathrm{NH}_{4}\right)_{2} \mathrm{SO}_{4}, 5 \mathrm{~g}$; $\mathrm{MgSO}_{4} .7 \mathrm{H}_{2} \mathrm{O}, 0.2 \mathrm{~g} ; \mathrm{K}_{2} \mathrm{HPO}_{4}, 2.5 \mathrm{~g} ; \mathrm{NaCl}, 5 \mathrm{~g}$; glucose $12.5 \mathrm{~g}$; proline, $0.5 \mathrm{~g}$; biotin, $0.05 \mathrm{~g}$. Cells were recovered by centrifugation, washed twice by centrifugation with sterile distilled water, resuspended in sterile distilled water and shaken at $28{ }^{\circ} \mathrm{C}$ until a minimal number of budding yeast cells were observed (usually 2-4h). Cells were recovered by centrifugation, resuspended in sterile distilled water and kept at $4{ }^{\circ} \mathrm{C}$ for at least $48 \mathrm{~h}$. Cells were inoculated into fresh Lee's medium and incubated at $28^{\circ} \mathrm{C}$ to obtain yeast growth, or at $37^{\circ} \mathrm{C}$ to obtain mycelial cells. When necessary, cells were radioactively labelled by growing in the presence of either $0.1 \mu \mathrm{Ci}$ $(3.7 \mathrm{MBq}) \mathrm{ml}^{-1}\left[{ }^{14} \mathrm{C}\right]$ protein hydrolysate $[\mathrm{sp}$. act. $56 \mathrm{mCi}$ $\left(2072 \mathrm{MBq}\right.$ ) carbon matom ${ }^{-1}$ ] [in Lee's medium containing $0.1 \%$ Casamino acids (Difco)]; or $0.4 \mu \mathrm{Ci}(14.8 \mathrm{MBq}) \mathrm{ml}^{-1}$ of [U- ${ }^{14} \mathrm{C}$ ]glucose [sp. act. $3 \mathrm{mCi} /(111 \mathrm{MBq}) \mathrm{mmol}^{-1}$ ].

Purification of cell walls and treatment with ethylenediamine (EDA). Small cell volumes resuspended in $50 \mathrm{mM}$ phosphate buffer pH 6.5 containing $1 \mathrm{mM}$ PMSF were broken in $12 \mathrm{ml}$ Corex tubes by mixing with about $4 \mathrm{~g}$ glass beads and shaking in a Vortex mixer. Larger volumes were also broken with glass beads, but in a Braun homogenizer. Breakage was assessed by phase-contrast microscopic observation. Extracts were centrifuged at 3500 r.p.m. and the sedimented cell walls were washed twice with phosphate buffer plus PMSF, twice with $1 \mathrm{M} \mathrm{NaCl}$ and twice with water. Cell walls were extracted with $2 \%$ SDS in a boiling water bath essentially as described by Elorza et al. (1985); they were then washed twice with water, twice with ethanol, and again twice with water. Cell walls were recovered after each treatment by centrifugation. Finally, cell walls were freeze-dried. Dried walls were extracted with anhydrous EDA essentially as described by Korn \& Northcote (1960) and Lyon \& Domer (1985) for $3 \mathrm{~d}$ at $37^{\circ} \mathrm{C}$ with occasional shaking, followed by centrifugation. When EDA extraction of the insoluble residue was repeated, only $1-4 \%$ of additional radioactive material was solubilized (data not shown). The residue insoluble in EDA (designated as fraction $C$ ) was washed four times with EDA, then with chloroform, and dried. The solubilized material was further fractionated by precipitation with ethanol at $-20^{\circ} \mathrm{C}$ overnight and centrifuged at $0^{\circ} \mathrm{C}$ at $10000 \mathrm{~g}$ for $15 \mathrm{~min}$. After washing with ethanol, the alcoholic precipitate was extracted four times with distilled water separating the soluble and insoluble materials by centrifugation. The supernatants (fraction A) were mixed, dialysed and freezedried, while the water-insoluble material (fraction B) was washed with ethanol and dried under vacuum. Polysaccharide composition of the different fractions labelled with $\left[{ }^{14} \mathrm{C}\right]$ glucose was analysed as desceitbed by Murgui et al. (1985).

Enzymic treatments. Zymolyase $20 \mathrm{~T}$ (Miles Laboratories) treatment was performed with a solution $\left(1 \mathrm{mg} \mathrm{ml}^{-1}\right)$ in
$1 \mathrm{mM}$ PMSF for $3 \mathrm{~h}$ at $30^{\circ} \mathrm{C}$. Digestion with chitinase (Sigma, $0.5 \mathrm{mg} \mathrm{ml}^{-1}$ in $10 \mathrm{mM}$ phosphate buffer $\mathrm{pH} \mathrm{7.0)}$ took place for $3 \mathrm{~h}$ at $30^{\circ} \mathrm{C}$. For Endo $\mathrm{H}$ (Miles Laboratories) treatment, samples were incubated for $4 \mathrm{~h}$ at $30^{\circ} \mathrm{C}$ with $10 \mathrm{mU}$ of enzyme $\mathrm{ml}^{-1}$ in $20 \mathrm{mM}$ citrate buffer $\mathrm{pH} 7.0$ containing $0.5 \mathrm{mM}$ PMSF. Digestion with partially purified $\beta$-1,6-glucanase from Penicillium brefeldianum (a kind gift from A. Marcilla, Dept. de Microbiología, Universitat de Valencia, Spain) was carried out in acetate buffer $\mathrm{pH} 4.4$ at $30^{\circ} \mathrm{C}$ for $6 \mathrm{~h}$. Pronase $\mathrm{E}$ (Sigma) was employed at a concentration of $2 \mathrm{mg} \mathrm{ml}^{-1}$ in $0.1 \mathrm{M}$ acetate buffer $\mathrm{pH} 5.5$. Incubation proceeded at $28^{\circ} \mathrm{C}$ for $6-15 \mathrm{~h}$.

Column chromatography. The following columns and elution conditions were employed. Analytical Sephacryl S300. A column measuring $0.55 \mathrm{~cm}$ i.d. $\times 26 \mathrm{~cm}$ was used. It was equilibrated and eluted with $50 \mathrm{mM}$ ammonium acetate containing $1 \mathrm{mM}$ sodium azide. Four-drop fractions $(145 \mu \mathrm{l}$ in volume) were recovered. The column was calibrated with blue dextran (void volume), glucose (total volume), catalase, ovalbumin, bovine serum albumin and lysozyme.

Preparative Sephacryl S200. A $1 \cdot 8 \times 41 \mathrm{~cm}$ column was used. It was equilibrated, eluted and calibrated as described above, but 1 - $\mathrm{ml}$ fractions were recovered.

BioGel $P_{2}$. A $1.5 \times 45 \mathrm{~cm}$ column was used. It was equilibrated and eluted as described above, but $0 \cdot 4-\mathrm{ml}$ fractions were recovered. The column was calibrated with bovine serum albumin $\left(\mathrm{V}_{0}\right)$, raffinose, maltose and glucose.

Dowex 50 in $\mathrm{H}^{+}$phase. Dowex 50 was thoroughly washed with $1 \mathrm{M} \mathrm{HCl}$ and water. A $0.55 \times 7 \mathrm{~cm}$ column was used. It was washed with water until the effluent appeared neutral. Samples were eluted with $10 \mathrm{ml}$ water and the retained material was eluted with $6 \mathrm{ml} 0.5 \mathrm{M} \mathrm{NH}_{4} \mathrm{OH}$.

WGA-Sepharose 6B (WGA-S, Sigma). A 0.55 $\times 12.5 \mathrm{~cm}$ column was used. Samples were slowly applied and eluted with a peristaltic pump. After loading, the column was left for $2.5 \mathrm{~h}$ at room temperature and washed with $20 \mathrm{ml}$ water. Retained material was eluted with $10 \mathrm{ml}$ of a solution of GlcNAc $\left(25 \mathrm{mg} \mathrm{m}^{-1}\right)$. In order to perform amino acid analysis of the samples, GlcNAC was removed by two successive runs in the BioGel $\mathrm{P}_{2}$ column.

Chemical analyses. Amino acid analyses of samples hydrolysed with $6 \mathrm{M} \mathrm{HCl}$ at $105^{\circ} \mathrm{C}$ under an atmosphere of $\mathrm{CO}_{2}$ were performed with commercial amino acid analysers. Hydrolysed samples were placed in a $\mathrm{CaCl}_{2}$-containing desiccator over $\mathrm{NaOH}$ pellets, and dried under vacuum at room temperature. Neutral sugars were measured with phenol-sulphuric acid (Dubois et al., 1956), N-Acetylglucosamine was measured as described by Reissig et al. (1955). Chitinase activity was measured as described by Roberts \& Selitrennikoff (1988). For chromatographic analysis of sugars, samples were hydrolysed with $2 \mathrm{M} \mathrm{HCl}$ at $100^{\circ} \mathrm{C}$. $\mathrm{HCl}$ was evaporated as described above and the sugars were separated by descending paper chromatography using a solvent system consisting of ethyl acetate:pyridine: water $(8: 2: 1$, by vol.). After drying, sugar spots were revealed with silver (Trevelyan et al., 1950).

Light microscopy. Distribution of cell wall polymers in EDA fractions ( $B$ and $C$ ) was analysed using fluorescein-concanavalin A (Con A-F) to detect mannan, and calcofluor white or fluorescein-wheat germ agglutinin (WGA-F) to locate chitin (Horisberger \& Volanthen, 1977; Herth, 1980). For Calcofluorwhite staining, samples were resuspended in $20 \mathrm{mM}$ Tris $/ \mathrm{HCl}$, $\mathrm{pH} 7 \cdot 0$, containing $0.15 \mathrm{M}$ sodium chloride and $50 \mathrm{mg}$ Calcofluor $\mathrm{ml}^{-1}$. After $5 \mathrm{~min}$ of incubation, samples were washed by centrifugation four times with distilled water. For lectin staining, samples were incubated in the dark for $30 \mathrm{~min}$ at room temperature with $0.5 \mathrm{mg}$ lectin conjugate $\mathrm{ml}^{-1}$ in a buffer 
Table 1. Polysaccharide composition and distribution in EDA fractions

Walls were isolated from yeast or mycelial cells grown in the presence of $\left[\mathrm{U}^{14} \mathrm{C}\right]$ glucose, extracted with SDS, and fractionated with EDA. A, Water-soluble fraction; B, water-insoluble, EDA-soluble fraction; C, EDA-insoluble fraction. ND, Not detected.

\begin{tabular}{|c|c|c|c|c|c|c|}
\hline & \multicolumn{3}{|c|}{ Yeast walls } & \multicolumn{3}{|c|}{ Mycelial walls } \\
\hline & $\mathbf{A}$ & $\mathbf{B}$ & C & $\mathbf{A}$ & $\mathbf{B}$ & $\mathbf{C}$ \\
\hline \multicolumn{7}{|c|}{ Radioactivity incorporated } \\
\hline $10^{-3} \times$ D.p.m. & 259 & $23 \cdot 5$ & 820 & 110 & 73 & 861 \\
\hline$\%$ of total & $23 \cdot 5$ & $2 \cdot 1$ & $74 \cdot 4$ & $10 \cdot 5$ & 7 & $82 \cdot 5$ \\
\hline \multicolumn{7}{|c|}{ Polysaccharide composition (\%) } \\
\hline Mannan & 61 & 1 & $21 \cdot 5$ & $55 \cdot 5$ & 1 & $15 \cdot 5$ \\
\hline Glucan & 39 & 96 & $66 \cdot 5$ & $44 \cdot 5$ & $95 \cdot 5$ & 67 \\
\hline Chitin & ND & 3 & $11 \cdot 5$ & ND & $3 \cdot 5$ & 17 \\
\hline \multicolumn{7}{|c|}{ Polysaccharide distribution (\%) } \\
\hline Mannan & $47 \cdot 8$ & 0.07 & $52 \cdot 1$ & 32 & $0 \cdot 4$ & $67 \cdot 6$ \\
\hline Glucan & $15 \cdot 2$ & $3 \cdot 4$ & $81 \cdot 4$ & $7 \cdot 2$ & 10 & $82 \cdot 8$ \\
\hline Chitin & 0 & $0 \cdot 8$ & $99 \cdot 2$ & 0 & $14 \cdot 9$ & $85 \cdot 1$ \\
\hline
\end{tabular}

solution containing $1 \mathrm{mM} \mathrm{CaCl}, \mathrm{MnCl}_{2}$ and $\mathrm{MgCl}_{2}$. After incubation, samples were thoroughly rinsed with Tris $/ \mathrm{HCl}$ buffer and observed in a microscope equipped with an epifluorescence attachment.

Miscellaneous. Numerical data represent averages of two experiments whose variation did not exceed $15 \%$.

\section{RESULTS}

\section{Fractionation of cell wall polysaccharides}

Yeast or mycelial walls labelled with $\left[{ }^{14} \mathrm{C}\right]$ glucose were extracted with hot SDS, lyophilized and extracted with anhydrous EDA as described in Methods. Distribution of radioactivity in EDA fractions is shown in Table 1. About $70-80 \%$ of the radioactivity remained in the yeast and mycelial $\mathrm{C}$ fractions, while the rest was rendered soluble (fractions A plus B). Fraction A accounted for $24 \%$ of the total yeast wall, and for only $10 \%$ of the mycelium wall. Fraction B represented only a small proportion of the wall, accounting for $2 \%$ in the yeast, and $7 \%$ in the mycelial walls.

Polysaccharide composition of the three EDA fractions was different (Table 1). Fraction A contained no chitin, and was made of 55-60\% mannan and 39-44\% glucan in both yeast and mycelial forms. Fraction B was composed almost exclusively of glucan with trace amounts of mannan and chitin. Again no significant difference was observed between yeast and mycelium. Fraction $C$ was made of a higher proportion of glucans, but the relative proportions of mannan and chitin were different in yeast and mycelial walls. As has been reported (Chattaway $e t$ al., 1968; Braun \& Calderone, 1978; Elorza et al., 1983), chitin values were significantly higher, and mannan content lower, in mycelial compared to yeast walls. Comparative analysis of the distribution of wall polysaccharides in the different EDA fractions yielded instructive results (Table 1). In general for each wall polysaccharide most remained in the insoluble (C) fraction, with the following order of enrichment: chitin $>$ glucan $>$ mannan. This differential distribution was more noticeable in mycelial walls. Perhaps the most interesting observation was the exceptionally high amount of chitin in the EDA-soluble, water-insoluble fraction B of mycelial walls $(15 \%)$ compared to the corresponding yeast fraction.

\section{Fractionation of cell-wall proteins}

Yeast or mycelial cell walls labelled with $\left[{ }^{14} \mathrm{C}\right]$ protein hydrolysate were treated with SDS and fractionated with EDA as described in Methods. No significant differences in the distribution of the radioactive protein in EDA fractions from yeast or mycelial walls were observed (Table 2). Fraction A contained over $50 \%$ of the protein in both yeast and mycelium. It must be noticed that fraction $\mathrm{B}$ contained less than $1 \%$ mannan, but more than $10 \%$ protein, whereas fraction $\mathrm{C}$ which contained most of the mannan, had only about $25 \%$ of the protein material.

\section{Partial transformation of EDA-soluble into EDA- insoluble material}

Exponentially-growing mycelial cells were labelled with $\left[{ }^{14} \mathrm{C}\right]$ protein hydrolysate and after $1 \mathrm{~h}$ the cells were washed with fresh Lee's medium to remove the nonincorporated radioactivity. Cells were divided into two aliquots and further incubated in non-radioactive Lee's medium for $1 \mathrm{~h}$ or $15 \mathrm{~h}$ respectively. Cell walls were obtained and treated with SDS. Walls were then treated with EDA and the radioactivity distributed among the different fractions was measured. No important differences were observed in fraction B obtained from walls chased for 1 or $15 \mathrm{~h}$ but very significant differences were observed in fraction $\mathrm{A}$ whose radioactivity decreased from $54 \%$ after $1 \mathrm{~h}$ chase to $36.5 \%$ after $15 \mathrm{~h}$ and in 
Table 2. Protein distribution in EDA fractions from yeast and mycelial cells

Walls were isolated from yeast or mycelial cells grown in the presence of $\left[{ }^{14} \mathrm{C}\right]$ protein hydrolysate, extracted with SDS, and fractionated with EDA.

\begin{tabular}{|lccc|}
\hline Walls & Fraction* & \multicolumn{2}{c|}{ Radioactivity } \\
\cline { 3 - 4 } & & $\mathbf{1 0}^{\mathbf{- 3}} \times$ D.p.m. & \% of total \\
\hline Yeast & $\mathrm{A}$ & 580 & 62 \\
& $\mathrm{~B}$ & 105 & $11 \cdot 2$ \\
& $\mathrm{C}$ & 250 & $26 \cdot 7$ \\
Mycelium & $\mathrm{A}$ & 530 & $59 \cdot 2$ \\
& $\mathrm{~B}$ & 135 & $15 \cdot 1$ \\
& $\mathrm{C}$ & 230 & $25 \cdot 7$ \\
\hline
\end{tabular}

* As described in Table 1.

Table 3. Amino acid composition of cell wall and fractions obtained by EDA treatment

\begin{tabular}{|c|c|c|c|c|}
\hline \multirow{2}{*}{$\begin{array}{l}\text { Amino } \\
\text { acid }\end{array}$} & \multirow{2}{*}{$\begin{array}{c}\text { Native } \\
\text { walls }\end{array}$} & \multicolumn{3}{|c|}{ Molar amount of amino acids (\%) } \\
\hline & & $\begin{array}{c}\text { Fraction } \\
\text { A }\end{array}$ & $\begin{array}{c}\text { Fraction } \\
\text { B }\end{array}$ & $\begin{array}{c}\text { Fraction } \\
\text { C }\end{array}$ \\
\hline Asp & 6.6 & $7 \cdot 0$ & $5 \cdot 5$ & $6 \cdot 7$ \\
\hline HydroPro & $0 \cdot 5$ & ND & ND & ND \\
\hline Thr & $18 \cdot 1$ & $21 \cdot 1$ & $15 \cdot 5$ & $9 \cdot 2$ \\
\hline Ser & $13 \cdot 3$ & $13 \cdot 3$ & $20 \cdot 6$ & $15 \cdot 2$ \\
\hline Glu & $10 \cdot 4$ & $12 \cdot 3$ & $9 \cdot 8$ & $11 \cdot 7$ \\
\hline Pro & $10 \cdot 1$ & $12 \cdot 2$ & $7 \cdot 6$ & ND \\
\hline Gly & 6.7 & $7 \cdot 1$ & $6 \cdot 8$ & $8 \cdot 1$ \\
\hline Ala* & - & - & $12 \cdot 4$ & $13 \cdot 9$ \\
\hline Val & $5 \cdot 7$ & $5 \cdot 8$ & $5 \cdot 6$ & $5 \cdot 5$ \\
\hline Cys & $2 \cdot 7$ & $0 \cdot 3$ & ND & ND \\
\hline Met & $2 \cdot 3$ & $3 \cdot 2$ & ND & ND \\
\hline Ile & $6 \cdot 1$ & $3 \cdot 4$ & $1 \cdot 6$ & $1 \cdot 8$ \\
\hline Leu & $4 \cdot 2$ & $2 \cdot 8$ & $4 \cdot 2$ & $3 \cdot 0$ \\
\hline Tyr & $3 \cdot 4$ & $4 \cdot 0$ & $2 \cdot 8$ & $2 \cdot 8$ \\
\hline Phe & $1 \cdot 5$ & $1 \cdot 4$ & $1 \cdot 4$ & $4 \cdot 6$ \\
\hline Lys & $5 \cdot 0$ & 3.5 & $4 \cdot 0$ & $4 \cdot 6$ \\
\hline $\mathrm{His}$ & $1 \cdot 6$ & 1.5 & 0.9 & $1 \cdot 2$ \\
\hline Arg & 1.4 & 0.9 & $1 \cdot 2$ & $1 \cdot 7$ \\
\hline
\end{tabular}

ND, Not detected.

* In the chromatographic separation method used for cell walls and fraction $\mathrm{A}$, alanine co-eluted with glucosamine.

fraction $\mathrm{C}$ where it increased from $23 \%$ to $40.5 \%$ under the same conditions.

\section{Amino acid analysis of native walls and EDA fractions}

Comparison of the amino acid compositions of the original SDS-extracted cell wall and the three fractions obtained by treatment with EDA revealed that they were extremely similar. Interestingly seven amino acids, threonine, serine, glutamic and aspartic acids, proline, glycine and alanine accounted for about $70 \%$ of the total protein mass (Table 3). This suggests that the covalently-bound proteins probably comprise a unique family.

In order to determine which were the amino acids more internally associated with the insoluble polysaccharides, we digested fractions $\mathrm{B}$ and $\mathrm{C}$ with pronase. Amino acid composition of the pronase-resistant fraction was compared with the one from the native wall. Results revealed that the amino acid composition before or after pronase digestion was extremely similar (not shown). In fact the only significant differences were the disappearance of isoleucine, phenylalanine, and leucine (only in fraction B) in the pronase-treated residues.

\section{Microscopic observations of water-insoluble EDA fractions}

Fraction B observed by phase-contrast microscopy, appeared in the form of an amorphous material, whereas fraction $\mathrm{C}$ maintained the morphology of the cell wall. Fraction B stained with Con A-F showed the fluorescence distributed all over the amorphous material, indicating the presence of mannoproteins throughout this material. Similar results were obtained with calcofluor-white, but some fluorescence appeared more intensely defined in distinct points. WGA-F stained only small defined areas over an almost non-fluorescent background. WGA specifically reacts with chitin, while calcofluor-white recognizes both chitin and glucan; the latter being responsible for the background. These results suggest that glucan but not chitin, is uniformly distributed throughout fraction B.

Fraction $\mathrm{C}$ ghosts appeared uniformly fluorescent when treated with calcofluor-white. Chitinase treatment did not alter their morphology but reduced the staining with WGA-F or calcofluor-white, appearing mainly in the bud scars (Fig. 1, panels b, c). The shape of fraction $\mathrm{C}$ was destroyed after degradation of the glucan skeleton with Zymolyase (Fig. 1, d, e, f), and appeared as an amorphous material similar to fraction $\mathrm{B}$. In this material, only the rings of chitin could be detected as a structural part of the wall after WGA-F or calcofluor-white staining (Fig. 1e, f). Fraction $\mathrm{C}$ before or after chitinase treatment (Fig. 1a) showed almost no fluorescence with ConA-F, but this was greatly increased after Zymolyase treatment (Fig. 1d). Microscopic studies performed as described above were repeated using mycelial cell walls with similar results (data not shown).

\section{Chromatographic separation of products obtained from enzymic degradation of fraction $C$}

Further studies of the structure of fraction $C$ labelied with $\left[{ }^{14} \mathrm{C}\right]$ protein hydrolysate were performed by chromatographic analysis of the material released by different enzymic treatments, in a molecular sieving column of Sephacryl S300 (see Methods). Treatment of fraction C with chitinase, solubilized high $M_{\mathrm{r}}$ components plus a significant amount of material which eluted in the total 

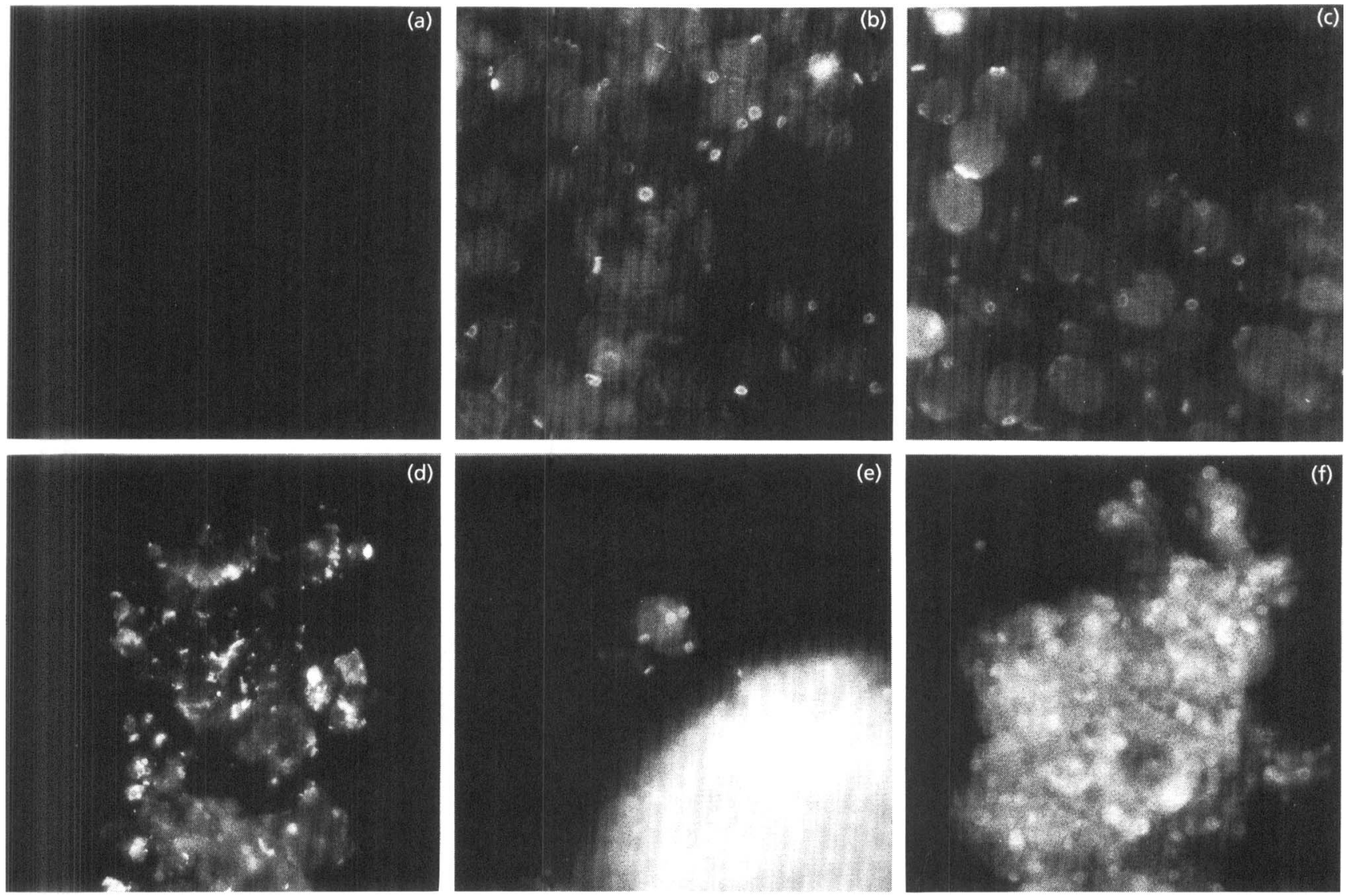

Fig. 1. Fluorescence microscopy of fraction $C$ treated with chitinase $(a, b, c)$ or Zymolyase (d, e, $f$ ). After EDA fractionation of yeast walls extracted with SDS, different aliquots of fraction $C$ were extracted with chitinase or Zymolyase, and stained with Con A-F $(a, d)$, calcofluor-white (b, e) or WGA-F $(c, f)$.

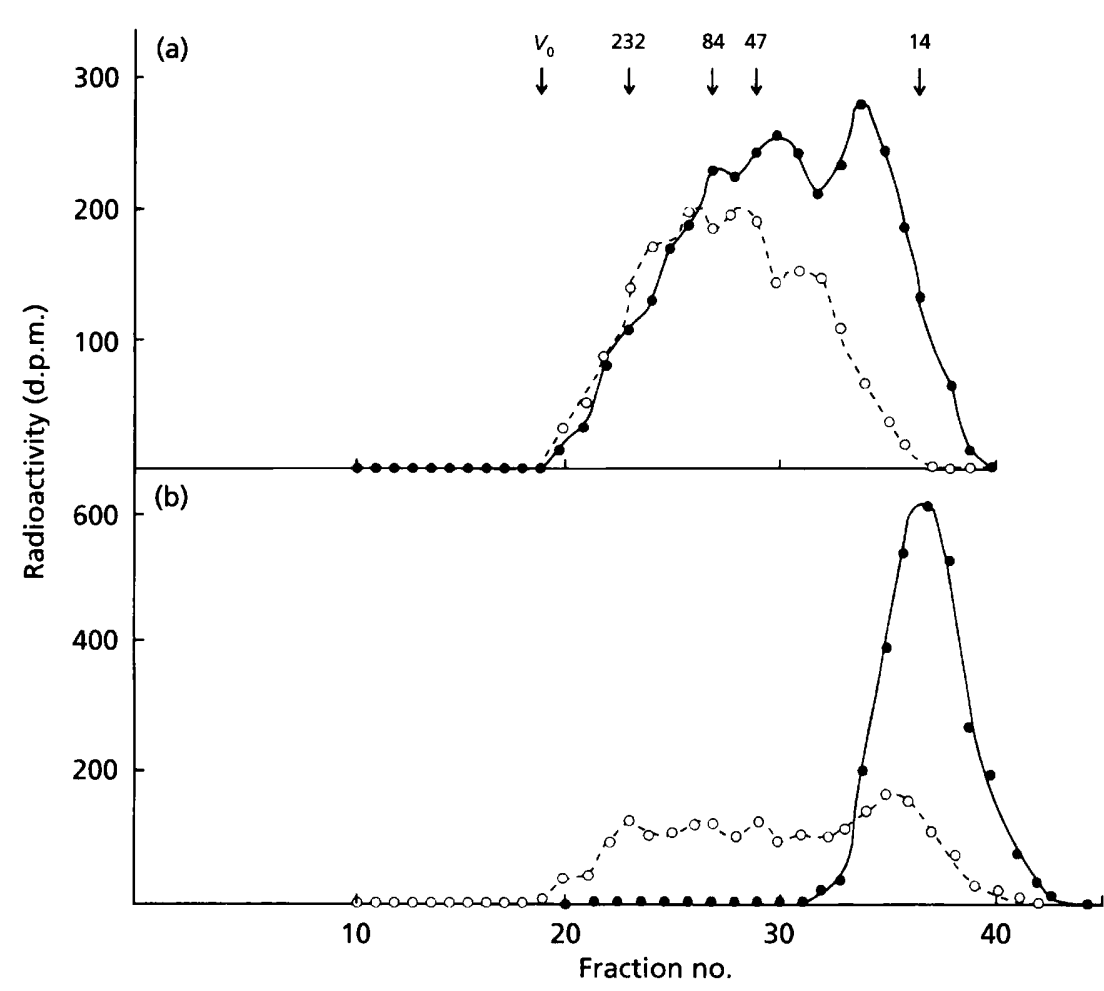

Fig. 2. Chromatographic behaviour of material released from insoluble fraction $C$ by chitinase and Zymolyase. (a) Fraction C labelled with amino acids was treated with chitinase (O) or Zymolyase $(O)$ and the released products were subjected to chromatography in a Sephacryl $\$ 300$ column. Fractions $(145 \mu \mathrm{l})$ were recovered and radioactivity was measured. (b) Radioactive residues obtained from fraction $C$ after Zymolyase (O) or chitinase (O) digestion were treated with chitinase $(\Theta)$ or Zymolyase $(O)$ and the solubilized products were separated in the same column as in (a). Arrows indicate elution volumes of protein standards of the corresponding molecular mass (in kDa). 


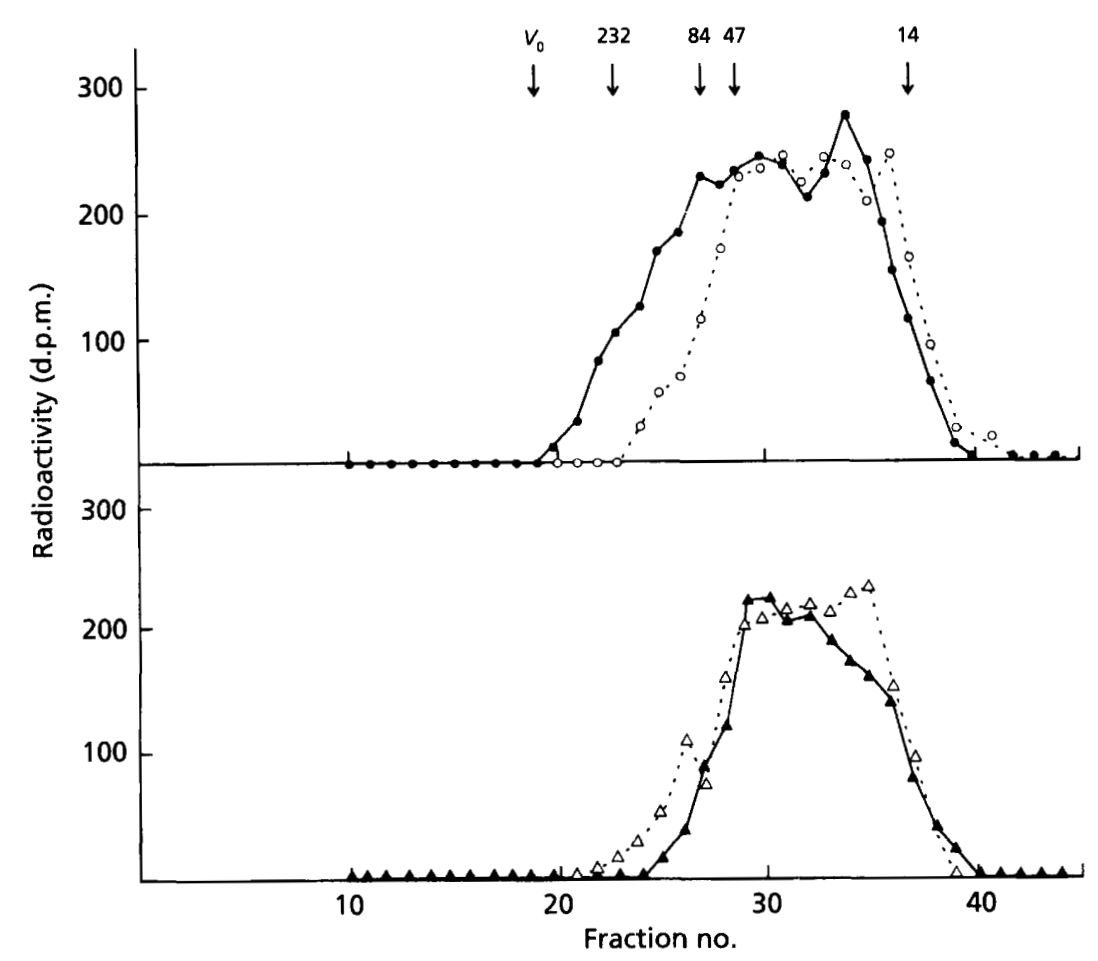

Fig. 3. Effect of glucanases and Endo $\mathrm{H}$ on the chitinase-solubilized products from fraction C. Material solubilized by chitinase from radioactive fraction $C$ was treated with buffer (O), $\beta$-1,3-glucanase (0), $\beta$-1,6glucanase $(\triangle)$ or Endo $H(\Delta)$. The products were separated and analysed as described in Fig. 2.

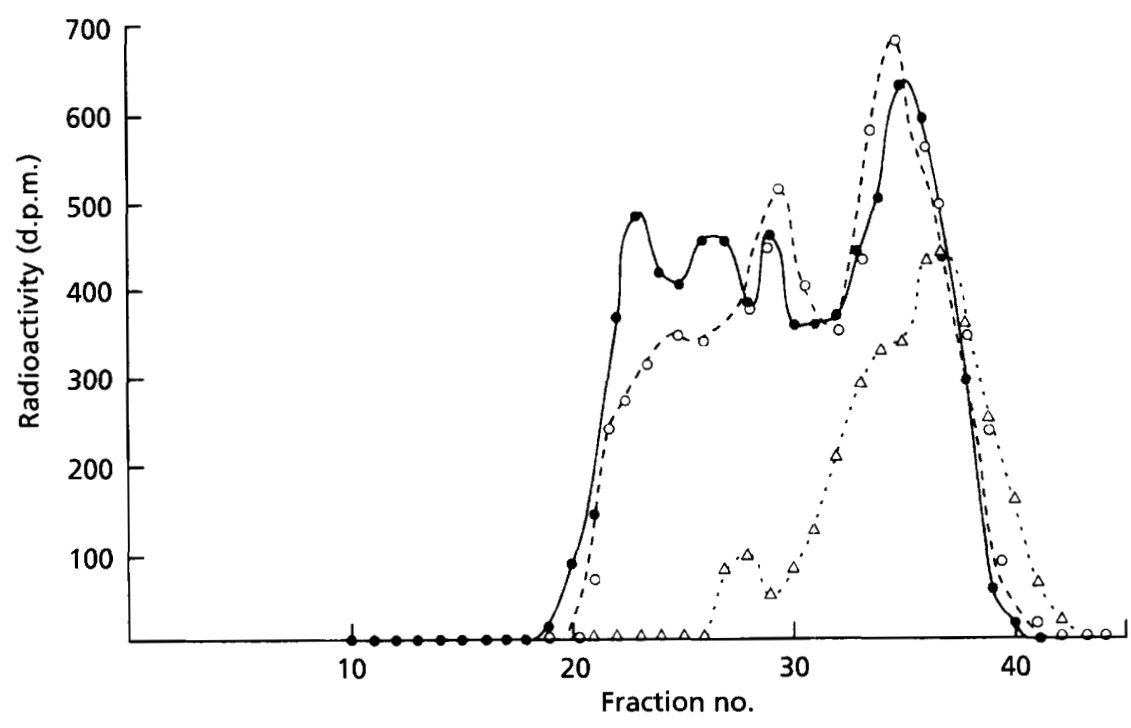

Fig. 4. Effect of Endo $H$ and pronase on the Zymolyase-solubilized products from fraction C. Material solubilized from radioactive fraction $C$ by Zymolyase, was incubated with buffer (O), Endo $\mathrm{H}(\mathrm{O})$, or pronase $(\triangle)$. The products were separated and analysed as described in Fig. 2. volume of the column (Fig. 2a). These latter low $M_{\text {r }}$ components were not released by Zymolyase (Fig. 2a); but when the Zymolyase-resistant residue was digested with chitinase, they appeared as the sole solubilized products (Fig. 2b). High $M_{\mathrm{r}}$ material plus small $M_{\mathrm{r}}$ components were released by Zymolyase from the chitinase-resistant residue (Fig. 2b).

The complex composition of the material solubilized by chitinase was assessed by successive treatments with other hydrolases. For example, either $\beta$-1,3- or $\beta$-1,6-glucanases reduced the $M_{\mathrm{r}}$ of the components solubilized by chitinase (Fig. 3), indicating that these contained glucan-bound protein. Also, Endo $\mathrm{H}$ reduced the $M_{\mathrm{r}}$ of the chitinasesoluble material (Fig. 3b), as well as the Zymolyasesolubilized components (Fig. 4), suggesting the presence of $N$-linked mannosyl chains in the complexes. As expected, pronase reduced the size of these complexes, but interestingly it left some high $M_{\mathrm{r}}$ residues, whose protein moieties resisted protease degradation (Fig. 4).

To gain information on the intimate association between 


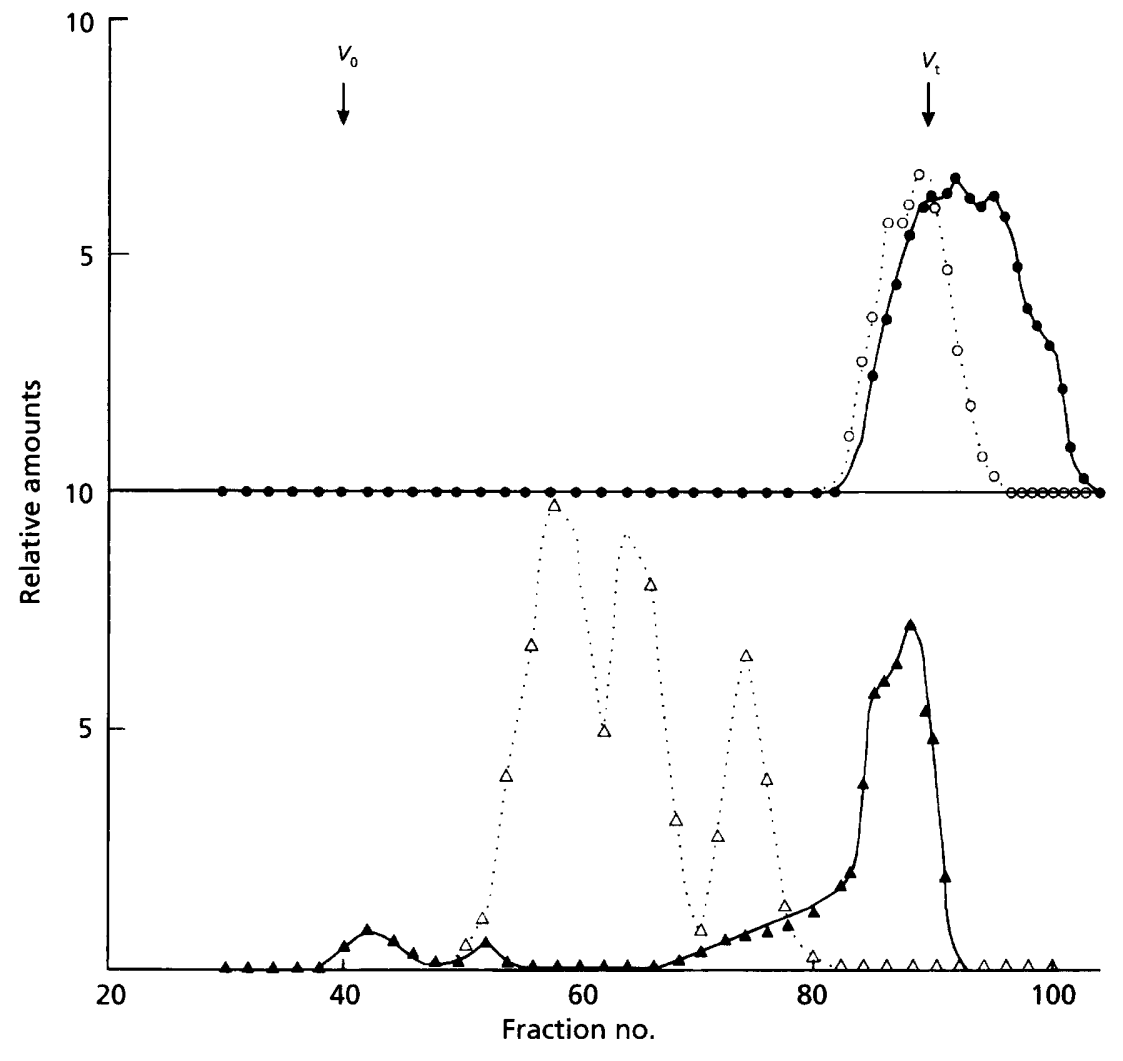

Fig. 5. Chromatographic behaviour in Sephacryl S200 of the products released by chitinase. The Zymolyase-resistant material from fraction $C$ was incubated with chitinase, the products were separated in a Sephacryl S200 column and $1 \mathrm{ml}$ fractions were recovered. Neutral sugars ( $\mathbf{\Delta})$, acetylaminosugars $(O)$, chitinase activity $(\triangle)$ and radioactivity (O) were measured in the fractions. A value of 10 in the ordinate corresponds to $5 \mathrm{mg}$ neutral sugar $\mathrm{ml}^{-1}$, $100 \mathrm{mg}^{2}$ acetyl amino sugar $\mathrm{ml}^{-1}$ (as free GleNAC), 1 chitinase unit, or 1000 d.p.m. $V_{0}$. void volume calculated with blue dextran; $V_{t}$, total volume calibrated with glucose.

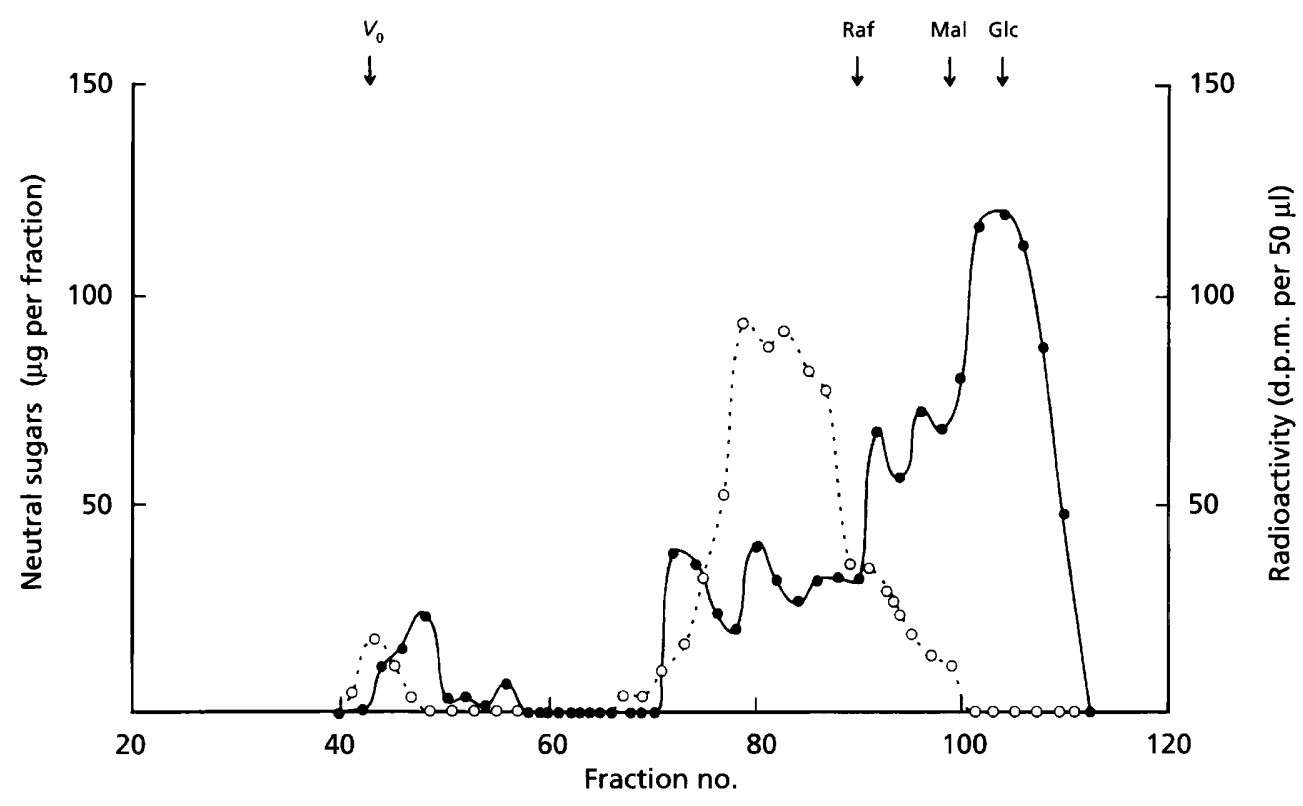

Fig. 6. Chromatographic elution in BioGel $P_{2}$ of the products released by chitinase from the Zymolyase-resistant material from fraction C. Material eluted in $V_{t}$ from Sephacryl S200 (Fig. 5) was subjected to chromatography in a BioGel $P_{2}$ column, and $0.4-\mathrm{ml}$ fractions were recovered. Neutral sugars $(O)$, and radioactivity $(O)$, were measured in each fraction. Arrows indicate the void volume $\left(V_{0}\right)$ and elution volumes of raffinose (Raf), maltose (Mal) and glucose (Glc).

the different wall polymers, fraction $C$ from both yeast and mycelium forms was treated with Zymolyase as described above, and the insoluble residue was incubated with chitinase. The released products were resolved in a column of Sephacryl S200. Chitinase activity, neutral sugars and acetyl-aminosugars were measured in the column effluent (Fig. 5). The low $M_{\mathrm{r}}$ material eluting in the total volume appeared free from chitinase and 
Table 4. Amino acid composition of the Zymolyaseresistant, chitinase-solubilized fragments of fraction $C$ (\$200) from the yeast and mycelial forms

\begin{tabular}{|lcc|}
\hline \multirow{2}{*}{ Amino acid } & \multicolumn{2}{c|}{ Molar amount of amino acids (\%) } \\
\cline { 2 - 3 } & Yeast & Mycelium \\
\hline Asp & $4 \cdot 9$ & $7 \cdot 7$ \\
Thr & $10 \cdot 4$ & $12 \cdot 6$ \\
Ser & $9 \cdot 5$ & $10 \cdot 0$ \\
Glu & $4 \cdot 6$ & $6 \cdot 2$ \\
Pro & $7 \cdot 1$ & $4 \cdot 3$ \\
Gly & $8 \cdot 8$ & ND \\
Val & $7 \cdot 8$ & $7 \cdot 0$ \\
Cys & $3 \cdot 4$ & $10 \cdot 7$ \\
Met & $1 \cdot 8$ & ND \\
Ile & $4 \cdot 5$ & $3 \cdot 2$ \\
Leu & $8 \cdot 9$ & $8 \cdot 4$ \\
Tyr & $4 \cdot 5$ & $3 \cdot 0$ \\
Phe & $3 \cdot 1$ & $4 \cdot 3$ \\
Lys & $12 \cdot 8$ & $13 \cdot 8$ \\
His & $3 \cdot 9$ & $2 \cdot 7$ \\
Arg & $3 \cdot 9$ & $5 \cdot 9$ \\
\hline
\end{tabular}

ND, Not detected.

Table 5. Amino acid analysis of chitinase-released oligomers separated in Dowex $50 \mathrm{H}^{+}$and WGA-S columns

\begin{tabular}{|lrrr|}
\hline \multirow{2}{*}{ Amino acid } & \multicolumn{3}{c|}{ Molar amount of amino acids (\%) } \\
\cline { 2 - 4 } & Fraction 1* & Fraction 2 $\dagger$ & Fraction 3 $\ddagger$ \\
\hline Asp & $1 \cdot 9$ & $10 \cdot 3$ & $2 \cdot 7$ \\
Thr & ND & $7 \cdot 5$ & ND \\
Ser & ND & $8 \cdot 7$ & $1 \cdot 3$ \\
Glu & ND & $5 \cdot 6$ & ND \\
Pro & ND & $4 \cdot 1$ & ND \\
Gly & $2 \cdot 4$ & $16 \cdot 8$ & $6 \cdot 3$ \\
Val & ND & $3 \cdot 9$ & $36 \cdot 3$ \\
Cys & $10 \cdot 5$ & $2 \cdot 6$ & ND \\
Met & ND & ND & ND \\
Ile & ND & $2 \cdot 1$ & ND \\
Leu & ND & $4 \cdot 7$ & $1 \cdot 9$ \\
Tyr & $12 \cdot 9$ & $11 \cdot 2$ & $8 \cdot 4$ \\
Phe & $6 \cdot 7$ & $2 \cdot 4$ & $5 \cdot 2$ \\
Lys & $55 \cdot 4$ & $15 \cdot 4$ & $22 \cdot 1$ \\
His & $10 \cdot 1$ & $10 \cdot 8$ & $9 \cdot 1$ \\
Arg & ND & $3 \cdot 7$ & ND \\
Orn & ND & ND & 6.6 \\
\hline
\end{tabular}

ND, Not detected.

* Fraction not retained in Dowex.

$\dagger$ Fraction retained in Dowex and eluted with $\mathrm{NH}_{4} \mathrm{OH}$.

$\ddagger$ Fraction retained in WGA-S. contained amino acids (by radioactivity), UV-absorbing material, neutral sugars and acetyl-aminosugars. This material was pooled, freeze-dried, and designated as S200.

Samples from S200 material were subjected to chromatography in a BioGel $\mathrm{P}_{2}$ column. Elution was followed by determination of neutral sugars and radioactivity (Fig. 6). It was observed that neutral sugars eluted in the form of mono- and oligosaccharides, whereas most of the amino acids appeared as oligomers larger than a trisaccharide. A small amount of both components eluted in the void volume. A pool was made of fractions containing the larger oligomers, but not the material eluted in $V_{0}$. After freeze-drying, samples were dissolved in $0.22 \mathrm{M} \mathrm{HCl}$ and subjected to chromatography in a Dowex $\mathrm{H}^{+}$column. Under these conditions amino acids, but not neutral sugars or GlcNAc, should bind to the column. Nevertheless, $20 \%$ of the neutral sugars were retained by the column, whereas $35 \%$ of the amino acids were not. Apparently neutral sugars were retained by Dowex because they were bound to amino acids, and a fraction of amino acids did not bind to the column because their amino groups had been blocked. Chromatography in WGA-S revealed that $35 \%$ of the amino acids (by radioactivity) present in the oligomer fraction were retained by the column, suggesting their association with GICNAc.

\section{Amino acid analysis of fractions separated from chitinase hydrolysates}

Fractions eluted from Sephacryl S200 from both yeast and mycelium revealed a similar amino acid composition (Table 4), which was very different from the original fraction $C$ (compare with data in Table 3). The main amino acid found in the Zymolyase-resistant, chitinasesolubilized fraction was lysine, and although threonine and serine remained abundant, glycine and proline were less well represented. When the ratio between glucosamine and amino acids was calculated, the higher ratio of the former in mycelium was confirmed: the yeast fraction contained $327 \mathrm{nmol}$ glucosamine per $100 \mathrm{nmol}$ of amino acids, whereas the corresponding value for mycelium was $827 \mathrm{nmol}$.

Amino acid analyses of the different oligomer samples separated in Dowex 50 and WGA-S columns were also performed. These fractions were: (1) not retained in Dowex; (2) retained in Dowex and eluted with $\mathrm{NH}_{4} \mathrm{OH}$; and (3) retained in WGA-S (Table 5). All three fractions, as already noticed, were enriched in lysine, but this amino acid was more abundant in fraction 1 (the fraction not retained in Dowex), where it represented $55 \%$ of the total amino acid content. In the material retained by the WGAS column, lysine represented $22 \%$ of the total amino acid residues, but valine was more abundant at $36 \%$. The amino acid composition of fraction 2 (retained in Dowex), was similar to the original Sephacryl S200 eluate, with the exception of glycine (see Table 4).

Glucosamine was present in all samples, although in different proportions. Thus fraction 1 contained 
$2340 \mathrm{nmol}$ per $100 \mathrm{nmol}$ of amino acids; fraction 2, 116; and fraction 3, 1256. Acid hydrolysis and paper chromatography revealed that all samples contained glucose as the main sugar, but fraction 1 also contained a small amount of mannose and traces of an unidentified pentose.

\section{DISCUSSION}

Previous studies by our group and other laboratories (Chattaway et al., 1968; Chaffin \& Stocco, 1983; Elorza et al., 1988; Surarit et al., 1988) have dealt with the analysis of the organization of $C$. albicans cell wall and have been aimed at understanding the wall properties and the changes occurring during the yeast-to-mycelium transition. These studies have utilized different approaches to provide information on chemical composition and polymer interactions. In the present work we have fractionated radiolabelled walls of $C$. albicans with anhydrous ethylenediamine in combination with enzymic hydrolysis to obtain further information on the organization of the wall polymers in this organism. Anhydrous EDA has been employed previously for the fractionation of walls from Saccharomyces cerevisiae (Korn \& Northcote, 1960), and C. albicans (Lyon \& Domer, 1985). It has the advantage over aqueous alkali solutions in that it preserves $O$-glycosidic linkages, and avoids destruction of labile proteins.

After SDS treatment to remove the non-covalently-linked wall proteins, fractionation of the total radiolabelled wall polysaccharides by EDA showed differences between yeast and mycelial cells. This treatment separated three fractions characterized by their different solubility properties. Fraction A (water soluble) was more than twice as abundant in yeast as in mycelial walls; while the mycelial fraction $\mathrm{B}$ (EDA-soluble, water-insoluble) was threefold higher than the yeast one. Fraction C (EDA-insoluble) was similarly represented in both morphological stages. These results confirm the different structural wall organization in both cell morphologies. Fraction A contained mannans and glucans in roughly similar proportions, while fraction $\mathrm{B}$ was made up almost completely of glucans. Fraction $C$ was enriched in glucans and chitin. Perhaps the most important difference was in chitin which was only present in trace amounts in yeast fraction $\mathrm{B}$, while in mycelium, $15 \%$ of the total chitin was present in this fraction. These results suggest the presence of two forms of chitin, one soluble and one insoluble in EDA, the former being more significant in mycelial cells. The size or crystallinity of this form of chitin is unknown. A non-fibrillar form of chitin, soluble in $7.5 \mathrm{M} \mathrm{NaOH}$ but insoluble in hot $2 \mathrm{M}$ alkali, was described in Trichophyton mentagrophytes (Pollack et al., 1983).

Of the protein content of the three EDA fractions, over $50 \%$ was present in fraction $A$, and the rest remained in the water-insoluble fractions $B$ and $C$. Interestingly, the ratio protein: mannan was different in each EDA fraction. It was highest in fraction $B$, and lowest in fraction $C$. The extent of glycosylation of wall glycoproteins may affect their solubility properties in EDA. It is also likely that proteins are rendered insoluble through their association with glucans and chitin. Chase experiments demonstrated that a significant fraction of EDA-soluble proteins became insoluble as incubation time increased. This result suggests that their further association with insoluble polymers occurs in the matrix of the wall.

Amino acid analysis showed that the bulk of the SDSresistant wall protein is very similar to the so called 'structural' protein studied in mnn9 mutants of Saccharomyces cerevisiae (Frevert \& Ballou, 1985). The unexpected result that the pronase-resistant residue had a similar amino acid composition, can be explained by assuming that some of the proteins remained protected from pronase. However this possibility requires that all of the wall proteins have a similar amino acid composition. A more appealing hypothesis, however, is that the core was protected from proteolysis by steric effects and was in the form of repeating units. Pronase treatment under our conditions left some high $M_{\mathrm{r}}$ fragments which probably represented the sugar-bound amino acid cores.

Microscopic studies of EDA fractions revealed that waterinsoluble fraction B appeared amorphous, whereas fraction $C$ retained the morphology of the original wall. Both fractions stained differently with fluorescent concanavalin A. Although fraction B contained only small amounts of mannan it stained heavily with the lectin, whereas fraction $C$ which contained much higher amounts of mannoproteins stained with ConA-F only after treatment with Zymolyase. This result suggests that glycoproteins are buried in the structural polysaccharides and are not accessible to the lectin until the wall structure becomes disorganized by the glucanase. Chitin was not homogeneously distributed in fraction B but appeared in the form of patches. Bud scars in fraction $C$ were resistant to treatment with Zymolyase, or chitinase. It is likely that the organization and association of both polymers in this region are different from the rest of the wall. Fraction $\mathrm{C}$ digested with chitinase retained its gross morphology, whereas glucan digestion brought about its almost complete breakdown leaving an amorphous residue. Accordingly it may be suggested that wall shape in $C$. albicans depends mostly on the organization of insoluble glucan.

Zymolyase released about $80 \%$ of the residual fraction $C$ protein leaving a residue, most of which was liberated by chitinase in the form of low $M_{\mathrm{r}}$ fractions. Reversing the order of glycosidase treatment revealed that chitinase releases high $M_{\mathrm{r}}$ fragments whose size can be reduced by $\beta$-1,6-glucanase, $\beta$-1,3-glucanase, or Endo $H$ treatments, suggesting that the residues are made of small chitin oligosaccharides covalently bound to large glucan tufts, plus polypeptides. Interestingly the $N$-linked polypeptide fragments resistant to Zymolyase which are tightly bound to chitin possess an amino acid composition significantly different from the more accessible bulk protein (see above), indicating that they correspond to a different protein family. It is pertinent to indicate here that Zymolyase preparations are contaminated with a protease which may digest the most accessible region of the covalently-bound proteins. 
The behaviour of the oligomers released from the Zymolyase-resistant core by chitinase treatment clearly revealed that they are mixtures of fragments, some of which contain covalently-bound GlcNAc, neutral sugars and amino acids. There was a remarkable abundance of lysine, in which both amino groups were apparently blocked and possibly bound to sugars. In Scbizopbyllum commune basic amino acids may be involved in the joining of chitin and glucan (Sietsma \& Wessels, 1979) although the precise nature of the bonds involved is unknown. On the other hand, evidence was found in regenerating protoplasts of $C$. albicans for the direct joining of $\beta-1,6-$ glucan to chitin through a glycosidic linkage involving the glucose-reducing end and the C6 position of GlcNAc (Surarit et al., 1988). Our data would be more in agreement with an indirect linkage through a dibasic amino acid.

\section{ACKNOWLEDGEMENTS}

This work was partially supported by Grants from CONACYT (México), Direccion General de Investigación Cientifica y Tecnica (PB 90-0424) (Spain), and the Commission of the European Community (L1*.0631.M).

\section{REFERENCES}

Benitez, T., Villa, T. G. \& Garcia-Acha, I. (1976). Some chemical and structural features of the conidial wall of Trichoderma viride. Can J Microbiol 22, 3318-3321.

Braun, P. C. \& Calderone, R. A. (1978). Chitin synthesis in Candida albicans: comparison of yeast and hyphal forms. J Bacteriol 133, 1472-1477.

Chaffin, W. L. \& Stocco, D. M. (1983). Cell wall mannoproteins of Candida albicans. Can J Microbiol 29, 1438-1444.

Chattaway, F. W., Holmes, M. R. \& Barlow, A. J. E. (1968). Cell wall composition of the mycelial and blastospore forms of Candida albicans. J Gen Microbiol 51, 367-376.

Dubois, M., Gilles, K. A., Hamilton, J. K., Rebers, P. A. \& Smith, F. (1956). Colorimetric method for determination of sugars and related substances. Anal Chem 28, 350-356.

Elorza, M. V., Rico, H. \& Sentandreu, R. (1983). Calcofluor white alters the assembly of chitin microfibrils in Saccharomyces cerevisiae. I Gen Microbiol 128, 1577-1582.

Elorza, M. V., Murgui, A. \& Sentandreu, R. (1985). Dimorphism in Candida albicans: contribution of mannoproteins to the architecture of yeast and mycelial cell walls. J Gen Microbiol 131, 2209-2216.

Elorza, M. V., Marcilla, A. \& Sentandreu, R. (1988). Wall mannoproteins of the yeast and mycelial cells of Candida albicans: nature of the glycosidic bonds and polydispersity of their mannan moieties. J Gen Microbiol 134, 2393-2403.

Elorza, M. V., Mormeneo, S., Garcia De La Cruz, R. F. \& Sentandreu, R. (1989). Evidence for the formation of covalent bonds between macromolecules in the domain of the wall of Candida albicans mycelial walls. Biochem Biophys Res Commun 162, $1118-1125$

Frevert, J. \& Ballou, C. E. (1985). Saccharomyces cerevisiae structural cell wall mannoprotein. Biochemistry 24, 753-759.

Herrero, E., Sanz, A. \& Sentandreu, R. (1987). Cell wall proteins liberated by zymolyase from several ascomycetous and imperfect yeasts. J Gen Microbiol 133, 2895-2903.

Herth, H. (1980). Calcofluor white and congo red inhibit chitin microfibril assembly of Poterioochromonas. Evidence for a gap between polymerization and microfibril formation. J Cell Biol 87, 442-450.

Horisberger, M. \& Volanthen, M. (1977). Localization of mannan and chitin on thin sections of budding yeast with gold markers. Arch Microbiol 115, 1-7.

Korn, E. D. \& Northcote, D. H. (1960). Physical and chemical properties of polysaccharides and glycoproteins of the yeast cell wall. Biocbem J 75, 12-17.

Lee, K., Buckley, H. R. \& Campbell, C. C. (1975). An amino acid liquid synthetic medium for the development of mycelial and yeast forms of Candida albicans. Sabouraudia 13, 148-153.

Lyon, F. L. \& Domer, J. E. (1985). Chemical and enzymatic variations in the cell wall of pathogenic Candida species. Can J Microbiol 31, 590-597.

Marcilla, A., Elorza, M. V., Mormeneo, S., Rico, H. \& Sentandreu, R. (1991). Candida albicans mycelial wall structure: supramolecular complexes released by Zymolyase, chitinase and $\beta$-mercaptoethanol. Arch Microbiol 155, 312-319.

Mol, P.C. \& Wessels, J. G. H. (1987). Linkages between glucosaminoglycan and glucan determine alkali-insolubility of the glucan in walls of Saccharomyces cerevisiae. FEMS Microbiol Lett 41, 95-99.

Murgui, A., Elorza, M. V. \& Sentandreu, R. (1985). Effect of papulacandin $B$ and calcofluor white on the incorporation of mannoproteins in the wall of Candida albicans blastospores. Biochim Biophys Acta 841, 215-222.

Pastor, F. I. J., Valentin, E., Herrero, E. \& Sentandreu, R. (1984). Structure of the Saccharomyces cerevisiae cell wall: mannoproteins released by zymolyase and their contribution to wall architecture. Biochim Biophys Acta 802, 292-300.

Pollack, J. H., Lange, C. F. \& Hashimoto, T. (1983). 'Nonfibrillar' chitin associated with walls and septa of Trichopbyton mentagrophytes arthrospores. J Bacteriol 154, 965-975.

Reissig, J. L., Strominger, J. L. \& Leloir, L. F. (1955). A modified colorimetric method for the estimation of $\mathrm{N}$-acetylamino sugars. $J$ Biol Chem 217, 959-966.

Roberts, W. K. \& Selitrennikoff, C. P. (1988). Plant and bacterial chitinases differ in antifungal activity. J Gen Microbiol 134, 169-176.

Ruiz-Herrera, J. (1992). Fungal Cell Wall: Structure, Synthesis and Assembly. Boca Raton: CRC Press.

Sanz, P., Herrero, E. \& Sentandreu, R. (1985). Autolytic release of mannoproteins from cell walls of Saccharomyces cerevisiae. $J$ Gen Microbiol 131, 2925-2932.

Sietsma, J. H. \& Wessels, J. G. H. (1979). Evidence for covalent linkages between chitin and $\beta$-glucan in a fungal wall. $J G e n$ Microbiol 114, 99-108.

Sietsma, J. H. \& Wessels, J. G. H. (1981). Solubility of $(1 \rightarrow 3)-\beta-$ $\mathrm{D} /(1 \rightarrow 6)-\beta$-D-glucan in fungal walls: importance of presumed linkage between glucan and chitin. J Gen Microbiol 125, 209-212.

Sonnenberg, A. S. M., Sietsma, J. H. \& Wessels, J. G. H. (1983). Biosynthesis of alkali-insoluble cell-wall glucan in Scbizopbyllum commune protoplasts. J Gen Microbiol 128, 2667-2674.

Surarit, R., Gopal, P. K. \& Shepherd, M. G. (1988). Evidence for a glycosidic linkage between chitin and glucan in the wall of Candida albicans. J Gen Microbiol 134, 1723-1730.

Trevelyan, W. F., Procter, D. P. \& Harrison, J. S. (1950). Detection of sugars on paper chromatograms. Nature 166, 444-445.

Valentin, E., Herrero, E., Pastor, F. I. J. \& Sentandreu, R. (1984). Solubilization and analysis of mannoprotein molecules from the cell wall of Saccharomyces cerevisiae. J Gen Microbiol 130, 1419-1428.

Van Rinsum, J., Klis, F. M. \& Van Den Ende, H. (1991). Cell wall 
glucomannoproteins of Saccharomyces cerevisiae mnn9. Yeast 7, 717-726.

Vries, O. M. H. \& Wessels, J. G. H. (1975). Chemical analysis of cell wall regeneration and reversion of protoplasts from Schizopbyllum commune. Arch Microbiol 102, 209-218.

Wessels, J. G. H. \& Sietsma, J. H. (1983). Wall synthesis and assembly during hyphal morphogenesis in Schizopbyllum commune. $J$ Gen Microbiol 129, 1607-1616.

Received 8 November 1993; revised 25 January 1994; accepted 11 February 1994. 